\title{
Extensive sheep grazing is associated with trends in steppe birds in Spain: recommendations for the Common Agricultural Policy
}

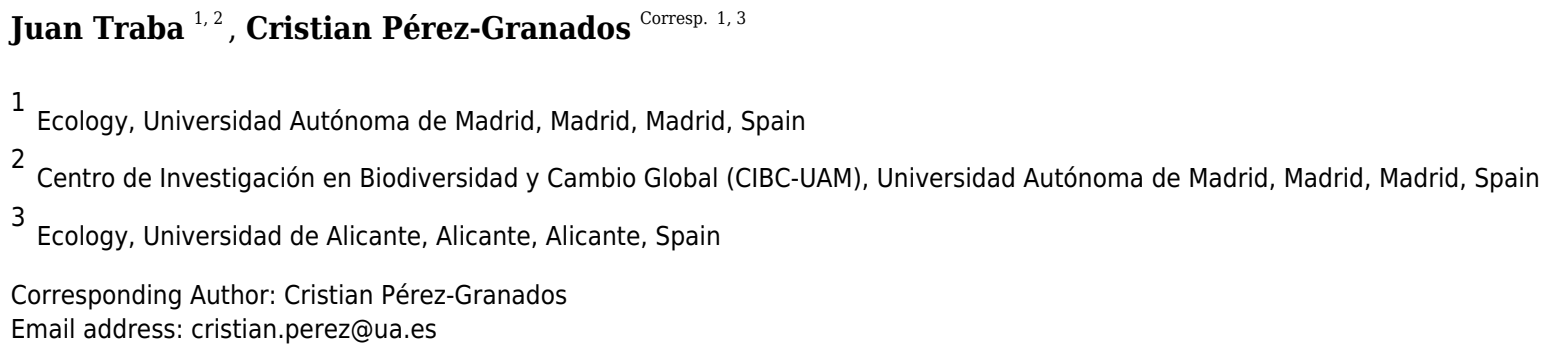

Iberian natural steppes have traditionally been used for extensive sheep grazing, which has been noted to be positively associated with steppe bird abundance and diversity. Sheep numbers in Spain, which harbors the largest European populations of many steppe bird species, decreased by 9.2 million (37.3\%) between 1992 and 2020. Steppe birds in Spain have faced dramatic declines during the same period, but there is a lack of knowledge about the potential association between sheep and open-habitat bird declines. We used sheep data from the Spanish Ministry of Agriculture and bird data (1998-2018) from the Spanish Common Bird Monitoring Program to assess the association at the Spanish scale between sheep decline and the Farmland Bird Index (FBI) and the Natural Shrub-steppe Bird Index (SBI). We also used an independent dataset on population trends of the Dupont's Lark (Chersophilus duponti) to assess the relationship between sheep numbers and the decline of this threatened steppe specialist passerine in Spain, whose European population is restricted to Iberian natural steppes. To test for a spurious relationship between temporal series, variables were tested for cointegration. After confirming cointegration, we found a strong positive relationship between sheep abundance and the trends of the FBI and SBI indices during the period 1998-2018. The association between sheep abundance and trends of the Dupont's Lark (2004-2015) was positive although it was not statistically significant. Although the main causes of decline of farmland and steppe birds are mainly related to agricultural intensification and land use changes, the correlation found, using two independent cointegrated datasets, between the reduction in farmland and shrub-steppe birds and sheep numbers at the country scale suggests that the decline of steppe birds in Spain may be also associated with the decline in sheep numbers. This agrees with previous studies that found a positive relationship between intermediate levels of sheep grazing and steppe bird abundance in Iberian 
steppes. Further research (e.g. experimental studies) is needed to corroborate our study and identify the most appropriate level of grazing intensity for protecting the most farmland and shrub-steppe birds. Our results suggest that the promotion of extensive grazing should be considered as a key factor in future Common Agricultural Policy reforms and conservation programmes to protect steppe birds. 
1 Extensive sheep grazing is associated with trends in steppe birds in Spain:

2 recommendations for the Common Agricultural Policy

3

4

5 JuAn TRABA ${ }^{1,2} \&$ CRISTIAN PÉREZ-GRANAdOS ${ }^{1,3, *}$

6

71 Terrestrial Ecology Group (TEG-UAM), Department of Ecology, Universidad Autónoma de

8 Madrid, Madrid, c/ Darwin, 2. 28049. Madrid, Spain

$9{ }^{2}$ Centro de Investigación en Biodiversidad y Cambio Global (CIBC-UAM). Universidad

10 Autónoma de Madrid, Madrid, c/ Darwin, 2. 28049. Madrid, Spain

$11{ }^{3}$ Ecology Department, Alicante University, PO Box 99, 03080 Alicante, Spain

12

13 Corresponding author: E-mail address: cristian.perez@ua.es. Tel: +34 (914978271). Fax: +34

14 (914978001). 
21 ABSTRACT

22 Iberian natural steppes have traditionally been used for extensive sheep grazing, which has been noted to be positively associated with steppe bird abundance and diversity. Sheep numbers in Spain, which harbors the largest European populations of many steppe bird species, decreased by 9.2 million (37.3\%) between 1992 and 2020. Steppe birds in Spain have faced dramatic declines during the same period, but there is a lack of knowledge about the potential association between sheep and open-habitat bird declines. We used sheep data from the Spanish Ministry of Agriculture and bird data (1998-2018) from the Spanish Common Bird Monitoring Program to assess the association at the Spanish scale between sheep decline and the Farmland Bird Index (FBI) and the Natural Shrub-steppe Bird Index (SBI). We also used an independent dataset on population trends of the Dupont's Lark (Chersophilus duponti) to assess the relationship between sheep numbers and the decline of this threatened steppe specialist passerine in Spain, whose European population is restricted to Iberian natural steppes. To test for a spurious relationship between temporal series, variables were tested for cointegration. After confirming cointegration, we found a strong positive relationship between sheep abundance and the trends of the FBI and SBI indices during the period 1998-2018. The association between sheep abundance and trends of the Dupont's Lark (2004-2015) was positive although it was not statistically significant. Although the main causes of decline of farmland and steppe birds are mainly related to agricultural intensification and land use changes, the correlation found, using two independent cointegrated datasets, between the reduction in farmland and shrub-steppe birds and sheep numbers at the country scale suggests that the decline of steppe birds in Spain may be also associated with the decline in sheep numbers. This agrees with previous studies that found a positive relationship between intermediate levels of sheep grazing and steppe bird abundance in 
44 Iberian steppes. Further research (e.g. experimental studies) is needed to corroborate our study

45 and identify the most appropriate level of grazing intensity for protecting the most farmland and

46 shrub-steppe birds. Our results suggest that the promotion of extensive grazing should be

47 considered as a key factor in future Common Agricultural Policy reforms and conservation

48 programmes to protect steppe birds.

50 Keywords: Chersophilus duponti, Farmland Bird Index, Steppe birds, extensive grazing, sheep,

51 steppes.

52

53

54

55

56

57

58

59

60

61

62

63

64

65

66

PeerJ reviewing PDF | (2021:10:66525:4:0:NEW 10 Jan 2022) 


\section{INTRODUCTION}

European natural and semi-natural open habitats, such as steppes, uplands and moorlands

(natural steppes hereinafter), are generally the result of altitudinal/climatic and edaphic tree-

limiting conditions, and regular low-intensity human disturbances such as low-yield agriculture, fire or livestock ${ }^{1}$. All these factors have shaped the characteristic open, tree-less landscape of such habitats ${ }^{2,3}$, which harbors high biodiversity values ${ }^{1}$. In these economically disadvantaged areas,sheep systems have been decisive in maintaining rural livelihoods, but also providing several ecosystem services, such as protecting biodiversity and maintaining natural resources ${ }^{4}$. However, sheep farm income in the European Union is supported by public subsidies, such as the Common Agricultural Policy ${ }^{5}$ (CAP hereinafter), which makes the sector strongly dependent on changes in the policy framework ${ }^{6,7,8}$.

Several works have suggested the existence of a complex system of multiple interactions where extensive sheep grazing affects plant structure spatial heterogeneity and plant species composition $^{9,10,11}$, as well as arthropod abundance both directly through its depositions and indirectly, by increasing habitat heterogeneity ${ }^{11,12,13}$. Heavy levels of grazing have proven to be disadvantageous for a large number of farmland and steppe birds, due to overconsumption of plants and high fertilization ${ }^{14}$. However, light or moderate grazing may have positive effects since grazing decreases vegetation height ${ }^{12,15}$, and facilitates the occurrence of coprophagous

87 species ${ }^{6,16,17}$. Moreover, the foraging efficiency of steppe birds increases in more open habitats ${ }^{14,18,19,20}$ and greater visibility in sparser vegetation minimizes the risk of predation for ground-standing birds ${ }^{19,21}$. All of these factors may favor the abundance and space use of 
90 insectivorous birds ${ }^{2,3,22,23}$. As a result, numerous threatened bird species have their strongholds in

91 these extensively sheep-grazed natural steppes ${ }^{24}$. Of particular conservation concern are the

92 Iberian natural steppes (shrub steppes, sensu ${ }^{25}$ ), which, as with many Mediterranean calcareous

93 grasslands, are the consequence of both anthropogenic and natural processes, with an important

94 role played by extensive grazing by sheep in the spring and autumn ${ }^{26,27}$. In Spain, sheep are

95 traditionally reared in extensive or semi-extensive systems due to the hardiness of the

96 autochthonous breeds and their good adaptation to adverse environmental conditions ${ }^{7}$.

97 Iberian natural steppes are among the European landscapes with the highest value for

98 biodiversity conservation, since they harbor the main (or the entire) European population of

99 several threatened steppe bird species, such as the Dupont's lark (Chersophilus duponti), the

100 Greater short-toed lark (Calandrella brachydactyla), the Stone curlew (Burhinus oedicnemus),

101 the Little bustard (Tetrax tetrax), both the Black-bellied (Pterocles orientalis) and Pin-tailed

102 sandgrouses (Pterocles alchata), and the Tawny pipit (Anthus campestris), among many others ${ }^{28}$.

103 Steppe and farmland birds are the most threatened group of birds in Europe ${ }^{29}$ and overall $83 \%$ of

104 the steppe bird species show an unfavorable conservation status in Europe ${ }^{30}$. Agricultural

105 intensification, together with habitat loss and land-use changes have partly caused the large

106 declines detected over the past several decades for open-habitat bird populations ${ }^{1,28,31,32}$. In

107 marginal regions such as those of Iberian natural steppes, where agricultural income has been

108 traditionally low, agricultural intensification is also occurring at a field scale ${ }^{33}$. However, the

109 negative trends for several steppe birds that only inhabit primary stages of vegetation succession

110 are especially linked to shrub encroachment ${ }^{34,35,36}$. The spread of shrubs and dominant

111 graminoids is one of the major consequences of grazing abandonment, altering local floristic and

112 edaphic conditions $s^{1,37}$ and ultimately affecting to the entire animal community ${ }^{34}$. 
113 During the second half of the 20th century, land abandonment due to rural depopulation

114 generated a reduction in extensive sheep farming in Spain, as well an increase in stocking

115 rates $^{38,39}$. However, changes in CAP subsidies during the 21 st century have also led to important

116 structural changes in the sector ${ }^{6}$. An example is the decoupling of CAP payments in 2003, which

117 provoked a decrease in sheep numbers in less-favoured areas, while the persistence of CAP

118 subsidies coupled to cattle and beef-cattle production has provoked a shift from sheep-based to

119 cattle-based systems in permanent pastures ${ }^{40,41,42}$, usually with an increase in stocking rate. All of

120 these changes have had a great impact on land use 38,43 and have led to an increase in shrub and

121 tree cover in these areas ${ }^{39}$. While a number of studies have assessed the relationship between

122 grazing pressure and bird abundance in farmlands and uplands in the United Kingdom ${ }^{2,3,31}$, our

123 current knowledge about the association between grazing and farmland and steppe birds in

124 Mediterranean landscapes is still limited (but see ${ }^{15,43,44}$ ).

125 In this study, we aimed to assess the variation in steppe bird abundance in relation to changes in

126 sheep abundance in Spain over the period 1998-2018. We estimated the nation-wide relationship

127 between trends in sheep abundance with an annual index in population trends estimated for 35

128 common farmland bird species (Farmland Bird Index, Table S1) and for 20 common bird species

129 typical of Iberian natural shrub-steppes (Steppe Bird Index, Table S2) to evaluate the potential

130 impact of changes in sheep numbers on abundance of open-habitat bird species. Additionally, we

131 also tested the relationship between trends in sheep numbers and population trends of the

132 Dupont's lark (Chersophilus duponti). We selected this species because it is a threatened habitat133 specialist whose European population is restricted to Iberian natural shrub-steppes ${ }^{45}$, and for

134 which accurate data have been collected during the last 15 years ${ }^{45}$. Moreover, the promotion of

135 extensive grazing has been traditionally described as one of the main conservation interventions 
136 to maintain optimal vegetation structure for the Dupont's lark (reviewed by ${ }^{46}$ ). Based on the

137 assumed positive impact that low-to-moderate grazing pressure has on steppe bird abundance ${ }^{12}$,

138 we expected to find a close association between the decline in sheep numbers and the decline in

139 the population indices estimated for the community of farmland and steppe birds, as well as for

140 the Dupont's lark. Our results might be useful in discussing the relationship between sheep

141 numbers and farmland and steppe birds and to formulate recommendations for agri-environment

142 schemes for these threatened groups of species.

MATERIAL AND METHODS

\section{Study area}

146 We focused the study in Spain, since this country is host to the largest proportion of steppe birds 147 in Europe ${ }^{28}$ and is ranked second in terms of numbers of sheep (ca. 19\% of the total ${ }^{47}$ ).

\section{Estimation of trends in sheep numbers}

Annual data on total number of sheep in Spain were obtained from the General Directorate of

Agricultural Productions and Markets (GDPME), of the Spanish Ministry of Agriculture,

Fisheries and Food MAPA ${ }^{48}$, for the period 1992-2020. Data come from surveys collected from all of the country's agrarian districts, and later scaled up to the province level. This is the only exhaustive nation-wide information on livestock numbers and trend. We restricted our analyses to sheep livestock and did not include goat livestock, since goat numbers are low in Spain (ca.

$15617 \%$ in respect to sheep livestock for the year 2020) and mainly restricted to certain regions ${ }^{48}$.

157 We estimated the trends in sheep numbers in Spain by calculating the trend (\%) since: a) 1992,

158 for the whole time period, b) 1998, for comparisons with Farmland and Shrub-steppe Bird 
159 Indices (see below), and c) since 2004 for comparisons with Dupont's lark trends, using each 160 mentioned year as the reference value (zero) in each analysis.

161

162 Estimation of trends in bird populations

163 For estimating farmland and steppe bird trends, we used bird data from the Spanish Common 164 Breeding Bird Monitoring Program (SACRE), which is hosted by the Spanish representative of 165 BirdLife (SEO/BirdLife). SACRE data is provided by volunteers who perform bird censuses in a 166 set of $10 \times 10 \mathrm{~km}$ cells distributed across the country (see Supplementary Fig. 1). These sites are 167 sampled annually, during the breeding season, following a standardized methodology. The

168 169

program currently involves over $1,000 \operatorname{sites}^{49}$. Although SACRE started in 1996, we selected data for the period 1998-2018, since during the first two years of the program data were collected from a reduced number of sites.

Census data are analysed by SEO/BirdLife, which provides a bird population abundance index for each species and year, estimated using the Trend and Indices for Monitoring data (TRIM) software by fitting log-linear regression models to count data with Poisson error terms ${ }^{50}$. These indices were converted on an annual trend (\%), using the year 1998 as baseline and following the same method described to estimate trends in sheep numbers. The trend of the TRIM population index can be used as an estimate of annual variations in the abundance of bird species $^{49,51}$ ( see $^{32}$ for a similar procedure). Indeed, the SACRE program provides the best information of population trends for common breeding bird species in Spain ${ }^{52,53}$. The indices of a group of species can be summarized into a single estimate to analyze trends of related bird species $^{54}$. Among these multi-species indices, the Farmland Bird Index (FBI) is notable. This is a summary population index that includes information of species classified as common farmland 
182 birds (e.g $\left.{ }^{51}\right)$. The FBI is an official index, adopted by the European Union, of the quality of EU's 183 agroecosystems for biodiversity and the effectiveness of agri-environmental interventions 184 applied under European $\mathrm{CAP}^{47}$. We used the official data provided by SEO/BirdLife for the FBI 185 index in Spain, which comprised data for 35 common farmland bird species (see Table S1). 186 Complementarily, we built a combined population index for a subset of 20 common species 187 typical of Iberian natural shrub-steppes (Steppe Bird Index, SBI, see Table S2; for species 188 selection see $25,28,55)$, to further explore the relationship of birds typical of shrub-steppes with the 189 variation in sheep numbers. The data about bird population index for each species and year was 190 also provided by SEO/BirdLife.

Finally, we used the Dupont's Lark (Chersophilus duponti), as a threatened habitat-

192 specialist of Mediterranean natural steppes, to evaluate the relationship between the abundance of this strong steppe-specialist lark and changes in sheep numbers. Due the difficulty of censusing this species using traditional surveys applied during the $\mathrm{SACRE}^{56}$, and thus the uncertainty in SACRE's Dupont's lark data, we used an independent dataset collected using a standardized, species-specific, counting method. Trend of Dupont's Lark population was estimated by Gómez-Catasús et al. ${ }^{45}$ over the period 2004-2015 in Spain, using the year 2004 as baseline. This dataset comprised $42 \%$ of the Spanish populations of the species, which can be considered as representative of the population trends of the species in $\mathrm{Spain}^{45}$. Annual trends were also estimated using the software $\mathrm{TRIM}^{45}$, similar to the method described for the SACRE program.

\section{Statistical analyses}


205 The application of regression models to time series can generate spurious relationships between

206 the considered variables, which although statistically related, may be purely coincidental ${ }^{57}$.

207 Durbin Watson is a test statistic used to detect the presence of autocorrelation in the residuals of

208 a regression analysis. If no causal relationship between the variables in a regression exists, the

209 variance increases over time (non-stationarity) and affects the Durbin Watson statistic, whose

210 low values may be due to this problem, and the coefficient of determination, which may reach

211 high values close to $1^{57}$. To deal with these problems, we carried out cointegration analyses

212 between variables in the regressions described below. Two variables are cointegrated when they

213 increase or decrease synchronously and maintain their relationship over time, suggesting a causal

214 relationship ${ }^{58}$. That is, when subtracting its expected value from the dependent variable, it is

215 stationary (that is, mean value is stable along the time series) ${ }^{58}$. We used the Johansen's method,

216 which assesses the validity of the cointegrating relationship using a maximum likelihood

217 estimates approach, to determine whether both variables are cointegrated. The null hypothesis for

218 such test is that there is no cointegration between variables ${ }^{59}$. Once it is determined if two

219 temporal series are cointegrated, traditional regression methods can be interpreted.

220 We fitted a linear regression to estimate the trend of sheep numbers over the period 1992-2020.

221 We fitted independent linear regressions to assess the relationship between bird population trends

222 (FBI, SBI) and sheep numbers, using trends of bird population as a variable response and the

223 trend in sheep numbers as an independent variable over the period 1998-2018, using the year

2241998 as a reference value (0). Finally, we assessed the relationship between the trends for

225 Dupont's lark and sheep numbers through linear regression. We used the overall trends of

226 Dupont's lark as a response variable and the trend in sheep numbers as an independent variable

227 over the period 2004-2015, using the year 2004 as a reference value (0). 
228 All statistics were performed with R 3.6.2 60 , using the package $l m e 4^{61}$ for linear regressions and

229 packages vars and urca for cointegration analyses ${ }^{62}$. The level of significance was $P<0.05$.

\section{RESULTS}

232

233

234

235

236

237

238

239

240

241

242

243

244

245

246

247

248

249

250

Sheep numbers significantly declined in Spain during the period 1992-2020 (Fig. 1). In 2020, there were $37.3 \%$ fewer sheep than in $1992(-9,175,782$ sheep; Linear regression, F-statistic $=$ 128.2.10, $\mathrm{df}=27$, adjusted $\mathrm{R}^{2}=0.82 ; \mathrm{p}<0.001$, see Table $\mathrm{S} 3$ for full statistics, Fig. 1$)$. The Johansen test showed significant cointegration between bird indices and sheep trends, which indicates that our results are unlikely to be due to spurious relationships: Spanish farmland bird trend $(\mathrm{FBI})$ vs. Sheep trends Johansen test $=26.82 ; \mathrm{p}<0.01$; Spanish steppe bird trend (SBI) vs. Sheep trend: Johansen test $=27.31 ; \mathrm{p}<0.01$; Dupont's lark trend (FBI) vs. Sheep trend: Johansen test $=25.02 ; \mathrm{p}<0.01$.

We found a strong, positive and significant relationship between the trend of Spanish farmland birds (FBI) during the period 1998-2018 and the sheep trend (Linear regression, F-statistic $=$ 39.85, $\mathrm{df}=19$, adjusted $\mathrm{R}^{2}=0.66, \mathrm{p}<0.001$, Fig. 2A, Table S3). Similarly, a positive and significant association was found between the trend of natural steppe birds (SBI) and the sheep trend for the same period (Linear regression, $\mathrm{F}$-statistic $=27.4, \mathrm{df}=19$, adjusted $\mathrm{R}^{2}=0.57$, $\mathrm{p}<0.001$, Fig. 2B, Table S3). The linear relationship between Dupont's lark trend and the sheep trend over the period 2004-2015 showed a positive relationship although it was not statistically significant (Linear regression, F-statistic $=4.44, \mathrm{df}=9$, adjusted $\mathrm{R}^{2}=0.26, \mathrm{p}=0.06$, Fig. 3, Table S3).

DISCUSSION 
251 Our results show a strong decline in sheep numbers in Spain during the last three decades, which

252 is in agreement with the decreasing number of sheep livestock in many European countries: 15\%

253 for the period 2002-2018 47,63,64,65,66. Nonetheless, the sheep decline detected in Spain has been

254 especially steep since 2007 , firstly, and even more so since 2009 , when the number of sheep

255 drastically declined (Fig. 1). This decrease in sheep numbers may be related to changes in CAP

256 subsidies and largely explained by the uncoupling of sheep subsidies that started in 2006 and

257 become permanent in 2010,42. After controlling for spurious correlations, we found a very strong

258 and positive relationship between the reduction in sheep numbers and the decline in farmland

259 and shrub-steppe birds at the national scale. The relationship between sheep numbers and the

260 population trend of the Dupont's Lark, a strong habitat specialist of Mediterranean natural

261 steppes $^{67}$, was just close to significant $(\mathrm{p}=0.06)$. This result was obtained using an independent

262 dataset $^{46}$ and at a shorter temporal scale (11 vs. 20 years) than FBI and SBI analyses. The lack of

263 a significant relationship for the Dupont's Lark case might be partly related to the more restricted

264 distribution range of the species, which may make it difficult to detect nation-wide changes.

265 Likewise, the decline in the Dupont's Lark has been associated with other land-use changes due

266 to human activity, such as habitat loss due to ploughing ${ }^{68}$ and the development of wind farms ${ }^{69}$,

267 which may have muddled our results.

268 We are aware that the decline in farmland and shrub-steppe birds in Spain is not exclusively

269 explained by the decline in sheep numbers, but our results and previous studies strongly suggest

270 that the significant relationships found are not simple correlations. It is well known that the

271 negative trends in farmland and steppe birds in Europe are mainly related to agricultural

272 intensification and land use changes, such as the decline in fallow lands ${ }^{32,70}$, which traditionally

273 were an important grazing source ${ }^{71}$, as well as the increase in the use of pesticides and 
274 herbicides $^{72,73}$, higher mechanization ${ }^{74}$, or the increase in trellis vineyards and irrigated woody

275 crops, which are largely unsuitable habitats for the considered groups of birds ${ }^{75,76}$, to cite a few.

276 Velado-Alonso et al. ${ }^{24}$ recently found strong geographical associations between steppe bird

277 richness and local sheep breed richness, which may be interpreted as an indicator of the intensity

278 of extensive sheep grazing. Though these relationships are probably mediated by other

279 environmental gradients, sheep grazing could have effects on increasing habitat heterogeneity,

280 which could help to promote steppe bird richness and abundance ${ }^{24}$.

281 The associations found between the decline in both sheep numbers and farmland and shrub-

282 steppe birds in Spain are in agreement with the well-recognized positive impact that extensive

283 grazing has on the distribution and abundance of farmland and steppe birds ${ }^{3,14,18,25,77}$ (but see ${ }^{14,78}$

284 for a negative effect of both heavy or very low levels of grazing in steppe birds). For example,

285 steppe birds are adapted to open habitats, which are partly maintained by light or moderate

286 grazing ${ }^{14}$. Grazing plays an important role by decreasing vegetation height and increasing spatial

287 heterogeneity ${ }^{11,15,78}$, which may increase the foraging efficiency of steppe birds by facilitating

288 foraging in more open habitats ${ }^{14,15,20,79}$ and minimizing their predation risk while foraging on the

289 ground $^{19,21}$. Sheep grazing has been described as a main driver of these habitats, as it may favor

290 open, creeping plant phenotypes, which disperse their seeds through the livestock dung ${ }^{80,81}$. The

291 amount of plants consumed by sheep in Mediterranean shrub steppes under extensive grazing has

292 been estimated at around $1500 \mathrm{~kg} / \mathrm{ha} /$ year (dry weight), while dung production is around 600

$293 \mathrm{~kg} / \mathrm{ha} / \mathrm{year}^{82}$. Moreover, sheep dung is twice as attractive to Mediterranean dung beetles as cattle

294 dung, three times more than red deer pellets, and four times more than horse dung ${ }^{83}$. Thus,

295 extensive sheep grazing will reduce plant structure and density ${ }^{10}$ and facilitate the occurrence of

296 dung-processing arthropods ${ }^{84}$, an important food source for some farmland and steppe 
297 birds ${ }^{12,13,16}$. Finally, these areas might be preferred by birds feeding on insects and especially on

298 dung beetles and other coprophagous arthropods ${ }^{15,16,22,23}$.

299 Goat abundance was around six times lower than sheep abundance in Spain in 2018, and

300 especially linked to specific regions. Thus, in this work we only considered trends in sheep

301 numbers. Nonetheless, the negative relationship between Iberian steppe birds and sheep numbers

302 was maintained when the trends in goat numbers in Spain were included, which was around -

$30310 \%$ during the period 2002-2018 according to official data ${ }^{48}$. Besides sheep number decline,

304 during the last decades there has also been a great change in livestock husbandry towards higher

305 intensification $^{43,62}$ that may alter the role that sheep play in natural steppes and other plant

306 communities. For example, in recent times sheep are more often kept indoors than free-ranging ${ }^{39}$

307 and the proportion of pregnant and lactating ewes, which are usually kept indoors, has

308 increased ${ }^{39,43,85}$. These changes in sheep husbandry imply a substantial reduction in the workload

309 and may maximize farmers' income, but reduce the intensity and duration of outdoor grazing 38,42 .

310 Under these circumstances, extensive sheep grazing in Spain has practically disappeared ${ }^{39}$, and

311 the role of sheep as an ecosystem engineer species has disappeared ${ }^{85}$ or has even become

312 negative due to pollution or overgrazing and soil degradation around intensive farms ${ }^{86,87}$. In

313 Spain, shrub- and tree-encroachment has steeply increased in areas considered as transitional

314 from former extensive grazing to current land abandonment ${ }^{39}$, and the consequences of this

315 functional change are yet to be fully determined.

316 Our results suggest that the alarming decline in Iberian farmland and shrub-steppe birds might

317 be, at least partly, associated with the sharp decline in sheep livestock occurring in Iberia.

318 Further research is needed to understand the role of sheep grazing in steppe and farmland bird

319 declines. In the meantime, there is a need to reverse the negative effect that this trend in sheep 
320 numbers may have on habitat heterogeneity and quality (i.e. food resources) for steppe birds. Our

321 findings suggest that extensive grazing should be considered as a key factor in future Common

322 Agricultural Policy reforms and conservation programs to stabilize, and even better increase, the

323 traditional sheep farming system. Such changes in CAP policies to promote sheep farming may

324 partially tackle other concerns in the EU, such as the preservation of biodiversity, reduction of

325 risks due to wildfire, valorization of environmentally friendly agricultural practices and

326 prevention of desertification ${ }^{42}$. Besides, changes from sheep to cattle, which could be seen as an

327 opportunity for farmers due to lower production and maintenance costs, has to be deeply

328 evaluated, as may provoke relevant changes in ecosystem structure and functionality ${ }^{40,41,42}$. As

329 the same grazing pressure may be favorable for some species of conservation concern but

330 detrimental to others ${ }^{15,44}$, we encourage researchers to estimate the adequate grazing intensity for

331 protecting most farmland and steppe birds, as well as to perform species-specific studies for

332 proposing a concrete grazing intensity to protect the most threatened species. These studies

333 would provide scientific evidence to managers and therefore increase the implementation of

334 extensive grazing as a conservation intervention ${ }^{88}$. Extensive sheep grazing should be promoted

335 as a multirole and low impact practice, which may contribute to increasing habitat heterogeneity,

336 reversing shrub encroachment and improving the situation for birds while avoiding the need to

337 apply other resource-consuming, and potentially hazardous practices such as mowing, manual

338 shrub-clearing and/or controlled burning ${ }^{1}$. In a climate change scenario, natural steppe habitats

339 may need habitat management actions aimed at improving habitat quality for open-habitat bird

340 species $^{15,88,89,90,91}$.

\section{ACKNOWLEDGEMENTS}


343 We wish to thank SEO/Birdlife and specifically Juan Carlos del Moral and Virginia Escandell

344 for providing SACRE data. We are grateful to Piotr Tryjanowski, Francisco Moreira, Rita Ramos

345 and one anonymous reviewer whose comments helped to improve the manuscript.

\section{REFERENCES}

$348{ }^{1}$ Carboni, M., DengLer, J., MantiLLa-Contreras, J., Venn, S. \& Török, P. Conservation value, 349 management and restoration of Europe's semi-natural open landscapes. Hacquetia 14, 5-17 350 (2015).

3512 Newton, I. The recent declines of farmland bird populations in Britain: an appraisal of causal 352 factors and conservation actions. Ibis 146, 579-600 (2004).

$353{ }^{3}$ Douglas, D. J. et al. Changes in upland bird abundances show associations with moorland 354 management. Bird Study, 64, 242-254 (2017).

3554 Spiegel, A. et al. Report on farmers' perceptions of risk and resilience capacities - a 356 comparison across EU farmers. SURE-Farm Deliverable 2.1, (H2020, No.727520) (2019).

$357{ }^{5}$ Bertolozzi C. D. Resilience of extensive sheep farming systems in Spain: strategies and policy 358 assessment. Doctoral dissertation, Agronomica. Universidad Politécnica de Madrid, Madrid, 359 Spain (2021).

$360{ }^{6}$ De Rancourt, M., Fois, N., Lavín, M. P., Tchakérian, E., \& Vallerand, F. Mediterranean sheep 361 and goats production: An uncertain future. Small Rumin, 62(3), 167-179 (2006)

$362{ }^{7}$ Castillo, L. P., Rubio, M. T. M., Puyalto, E. F., \& Sepúlveda, W. S. The diversity of sheep 363 production systems in Aragón (Spain): characterisation and typification of meat sheep farms. 364 Span J Agric Res, 4, 497-507 (2008) 
$365{ }^{8}$ Reino, L. et al. Effects of changed grazing regimes and habitat fragmentation on Mediterranean

366 grassland birds. Agric Ecosyst Environ, 138(1-2), 27-34 (2010).

3679 Kurek, P., Steppa, R., Grzywaczewski, G., \& Tryjanowski, P. The silence of the lambs? Plant

368 diversity in abandoned sheep pens. Plant, Soil and Environ, 62(1), 1-8 (2016).

$369{ }^{10}$ Adler, P., Raff, D. \& Lauenroth, W. The effect of grazing on the spatial heterogeneity of

370 vegetation. Oecologia, 128(4), 465-479 (2001).

$371{ }^{11}$ Bugalho, M. N., Lecomte, X., Gonçalves, M., Caldeira, M. C. \& Branco, M. Establishing 372 grazing and grazing-excluded patches increases plant and invertebrate diversity in a

373 Mediterranean oak woodland. Forest Ecol. Manag. 261, 2133-2139 (2011).

37412 Vickery, J. A. et al. The management of lowland neutral grasslands in Britain: effects of 375 agricultural practices on birds and their food resources. J. App. Ecol. 38, 647-664 (2001).

$376{ }^{13}$ Dennis, P. et al. The effects of livestock grazing on foliar arthropods associated with bird diet 377 in upland grasslands of Scotland. J. App. Ecol. 45, 279-287 (2008).

$378{ }^{14}$ Fuller, R. J. Relationships between grazing and birds with particular reference to sheep in the 379 British uplands. BTO Research Report No. 164. Norfolk. United Kingdom (1996).

$380{ }^{15}$ Leal, A. I., Acácio, M., Meyer, C. F., Rainho, A. \& Palmeirim, J. M. Grazing improves habitat 381 suitability for many ground foraging birds in Mediterranean wooded grasslands. Agric. Ecosyst. 382 Environ. 270, 1-8 (2019).

38316 Jay-Robert, P. et al. Relative efficiency of extensive grazing vs. wild ungulates management 384 for dung beetle conservation in a heterogeneous landscape from Southern Europe (Scarabaeinae, 385 Aphodiinae, Geotrupinae). Biol. Conserv. 141, 2879-2887 (2008). 
386

387

388

389

390

391

392

393

394

395

396

397

398

399

400

401

402

403

404

405

406

407

${ }^{17}$ Perrin, W., Jay-Robert, P., Buatois, B. \& Tatin, L. A comparative analysis of dung beetle assemblages (Coleoptera: Scarabaeidae: Scarabaeinae, Aphodiinae) attracted to sheep and little bustard excrement in Southern France. The Coleopterists Bull. 73, 185-192 (2019).

${ }^{18}$ Haworth, P. F. \& Thompson, D. B. A. Factors associated with the breeding distribution of upland birds in the South Pennines, England. J. App. Ecol. 27, 562-577 (1990).

${ }^{19}$ Buckingham, D. L. \& Peach, W. J. The influence of livestock management on habitat quality for farmland birds. Anim. Sci. 81, 199-203. (2005).

${ }^{20}$ Zbyryt, A., Sparks, T. H. \& Tryjanowski, P. Foraging efficiency of white stork Ciconia ciconia significantly increases in pastures containing cows. Acta Oecologica, 104, 103544 (2020).

${ }^{21}$ Whittingham, M. J. \& Evans, K. L. The effects of habitat structure on predation risk of birds in agricultural landscapes. Ibis 146, 210-220 (2004).

22 Gómez-Catasús, J., Garza, V., Morales, M.B. \& Traba, J. Hierarchical habitat-use by an endangered steppe bird in fragmented landscapes is associated with large connected patches and high food availability. Sci. Rep. 9, 19010 (2019).

${ }^{23}$ Smith, B.M. et al. The potential of arable weeds to reverse invertebrate declines and associated ecosystem services in cereal crops. Front. Sustain. Food Syst. 3, 118 (2020).

${ }^{24}$ Velado-Alonso, E., Morales-Castilla, I., Rebollo, S. \& Gómez-Sal, A. Relationships between the distribution of wildlife and livestock diversity. Div. Distrib. 26, 1264-1275 (2020).

25 Traba, J., Sastre, P. \& Morales, M.B. Factors determining species richness and community composition in steppe birds of peninsular Spain. In: Morales, M.B. \& Traba, J. (eds.) (2013) Steppe Ecosystems: Biological Diversity, Management and Restoration. pp: 29-46. NOVA Science Publishers, New York (2013). 
$408{ }^{26}$ Suárez, F. Mediterranean steppe conservation: A background for the development of a future

409 strategy. Doc. XI /153/94. European Commission, Brussels, 62 pp (1994).

41027 Sainz Ollero, H. Steppes across the World: An overview with emphasis on the Iberian

411 Peninsula. In: Morales, M.B. \& Traba, J. (eds) Steppe ecosystems: Biological diversity,

412 management and restoration, pp: 1-26. Nova Science Publishers, New York (2013).

$413{ }^{28}$ Santos, T. \& Suárez, F. Biogeography and population trends of Iberian steppe birds. In: Bota

414 G, Morales MB, Mañosa S, Camprodon J (eds) Ecology and conservation of steppe-land birds.

415 Lynx Edicions \& Centre Tecnològic Forestal de Catalunya, Barcelona, pp 69-102 (2005).

$416{ }^{29}$ EEA (European Environment Agency). State of nature in the EU. Results from reporting under

417 the nature directives 2007-2012. European Environment Agency, Technical report No 2/2015 418 (2015).

$419{ }^{30}$ Burfield, I. The conservation status of steppic birds in Europe. In: Bota G, Morales MB, 420 Mañosa S, Camprodon J (eds) Ecology and conservation of steppe-land birds: 119-139. Lynx 421 Edicions \& Centre Tecnològic Forestal de Catalunya, Barcelona. (2005).

$422{ }^{31}$ Fuller, R. J. \& Gough, S. J. Changes in sheep numbers in Britain: implications for bird 423 populations. Biol. Conserv. 91, 73-89 (1999).

42432 Traba, J. \& Morales, M. B. The decline of farmland birds in Spain is strongly associated to the 425 loss of fallowland. Sci. Rep. 9, 9473 (2019).

$426{ }^{33}$ Reverter, M., Gómez-Catasús, J., Barrero, A. \& Traba, J. Crops modify habitat quality beyond 427 their limits. Agric Ecosyst Environ, 319, 107542 (2021).

$428{ }^{34}$ Robinson, R.A. \& Sutherland, W.J. Post-war changes in arable farming and biodiversity in 429 Great Britain. J. App. Ecol. 39, 157-176 (2002). 
43035 Herrando, S., Anton, M., Sardà-Palomera, F., Bota, G., Gregory, R. D. \& Brotons, L.

431 Indicators of the impact of land use changes using large-scale bird surveys: land abandonment in 432 a Mediterranean region. Ecol. Ind. 45, 235-244 (2014).

$433{ }^{36}$ Holmes, A. L., Maestas, J. D. \& Naugle, D. E. Bird responses to removal of western juniper in 434 sagebrush-steppe. Rangeland Ecol. Manag. 70, 87-94 (2017).

$435{ }^{37}$ Koch, B., Edwards, P. J., Blanckenhorn, W. U., Walter, T. \& Hofer, G. Shrub encroachment 436 affects the diversity of plants, butterflies, and grasshoppers on two Swiss subalpine pastures. 437 Arct. Antarct. Alp. Res. 47, 345-357. (2015).

43838 Soto, D. et al. The social metabolism of biomass in Spain, 1900-2008: From food to 439 feed-oriented changes in the agro-ecosystems. Ecol. Econom. 128, 130-138 (2016).

$440{ }^{39}$ Martínez-Valderrama, J., Sanjuán, M.E., del Barrio, G., Guirado, E., Ruiz, A. \& Maestre, F.T. 441 Mediterranean Landscape Re-Greening at the Expense of South American Agricultural 442 Expansion. Land, 10, 204 (2021).

${ }^{40}$ Ramos, R. F., Diogo, J. A., Santana, J., Silva, J. P., Reino, L., Schindler, S., ... \& Moreira, F. 444 Impacts of sheep versus cattle livestock systems on birds of Mediterranean grasslands. Sci rep, 445 11(1), $10827(2021)$.

44641 Faria, N., \& Morales, M. B. Livestock species and grazing rotational patterns modulate 447 grassland bird assemblages in Mediterranean drylands. Agric Ecosyst Environ, 295, 106893 448 (2020).

$449{ }^{42}$ Mújica, P. M. T., Aguilar, C., Vera, R. R., Capote, C. B., Rivas, J., \& Martínez, A. G. Changes 450 in the pastoral sheep systems of semi-arid Mediterranean areas: association with common 451 agricultural policy reform and implications for sustainability. Span J Agric Res, 13(2), 19 (2015). 
$452{ }^{43}$ Riedel, J. L., Casasús, I. \& Bernués, A. Sheep farming intensification and utilization of natural

453 resources in a Mediterranean pastoral agro-ecosystem. Livestock Science, 111, 153-163 (2007).

45444 Reino, L. et al. Effects of changed grazing regimes and habitat fragmentation on

455 Mediterranean grassland birds. Agric. Ecosyst. Environ. 138, 27-34 (2010).

45645 Gómez-Catasús, J. et al. European population trends and current conservation status of an

457 endangered steppe-bird species: the Dupont's lark Chersophilus duponti. PeerJ 6, e5627 (2018).

45846 Pérez-Granados, C. \& López-Iborra, G.M. Research-conservation gap: An endangered bird 459 case study. Oryx, doi:10.1017/S003060532000023X (2021).

$46047 \quad$ Eurostat. Statistics explained. http://ec.europa.eu/eurostat/statistics461 explained/index.php/Main_Page (Last accessed 2020.03.01) (2020).

$46248 \quad$ MAPA. Statistics, https:/www.mapa.gob.es/es/estadistica/temas/estadisticas463 agrarias/ganaderia/encuestas-ganaderas/ (Last accessed 2021.09.20) (2020).

$464{ }^{49}$ Gordo, O. Are Two Days Enough? Checking the Accuracy of the Survey Protocols Used in 465 Common Bird Monitoring Schemes. Ardeola 65, 41-52 (2018).

$466{ }^{50}$ Pannekoek, J. \& Strien, A. Van TRIM version 3.54 (trends and indices for monitoring data).

467 (Statistic, Voorburg) (2006).

$468{ }^{51}$ Stjernman, M. et al. Habitat-specific bird trends and their effect on the Farmland Bird Index.

469 Ecol. Ind. 24, 382-391 (2013).

$470 \quad 52 \mathrm{SEO} /$ BirdLife. Programas de seguimiento y grupos de trabajo de ${ }^{41}$. Madrid, Spain (2016).

$471{ }^{53}$ Casas, F. et al. Opposing population trajectories in two Bustard species: A long-term study in a 472 protected area in Central Spain. Bird Conserv. Int. 29, 308-320 (2019) 
47354 Bowler, D. E., Heldbjerg, H., Fox, A. D., de Jong, M. \& Böhning-Gaese, K. Long-term

474 declines of European insectivorous bird populations and potential causes. Conserv. Biol. 33, 475 1120-1130 (2019).

47655 Traba, J., de la Morena, E.L.G., Morales, M.B. \& Suárez, F. Determining high value areas for 477 steppe birds in Spain: hot spots, complementarity and the efficiency of protected areas. Biod. 478 Conserv. 16, 3255-3275 (2007).

$479{ }^{56}$ Pérez-Granados, C. \& López-Iborra, G.M. Assessment of counting methods for estimating the 480 endangered Dupont's lark Chersophilus duponti. Ardeola, 64, 75-84 (2017).

48157 Granger, C.W.J. \& Newbold, P. Spurious Regressions in Econometrics. Journal of 482 Econometrics, 2, 111-120 (1974).

48358 Engle, R. \& Granger, C.W.J. Co-integration and error correction: representation, estimation 484 and testing. Econometrica 35, 251-276 (1987).

48559 Johansen, S. Statistical Analysis of Cointegration Vectors. Journal of Economic Dynamics and 486 Control, 112, 231-254 (1988).

$487{ }^{60} \mathrm{R}$ Development Core Team. R: a language and environment for statistical computing. R 488 Foundation for Statistical Computing, Vienna. http://www.R-project.org. (2019).

$489{ }^{61}$ Bates. D., Mächler. M., Bolker. B. \& Walker. S. Fitting linear mixed-effects models using 490 lme4. J. Stat. Software 67, 1-48 (2015).

49162 Eddelbuettel, D. Analysis of Integrated and Cointegrated Time Series with R (2nd 492 Edition). Journal of Statistical Software, 2009, 30, 1-2 (2009).

$493{ }^{63}$ Pollock, M. L., Holland, J. P., Morgan-Davies, C., Morgan-Davies, J. \& Waterhouse, A. 494 Reduced sheep grazing and biodiversity: a novel approach to selecting and measuring 495 biodiversity indicators. Rangeland Ecol. Manag. 66, 387-400. (2013). 
496

497 pastures. In: Hartel, T., Plieninger, T. (Eds.), European Wood-pastures in Transition. Routledge,

498 London, New York, pp. 187-202 (2014).

$499{ }^{65}$ Varga, A. et al. Changing year-round habitat use of extensively grazing cattle, sheep and pigs

500 in East-Central Europe between 1940 and 2014: Consequences for conservation and policy.

501 Agric. Ecosyst. Environ. 234, 142-153. (2016).

$502{ }^{66}$ De Arriba, R., \& Barac, M. Homo economicus and the shepherd: The traditional sheep farmer 503 facing the modernization (or intensification) of European livestock. Eastern European 504 Countryside, 24, 171-187 (2018).

$515300(2010)$.

$516{ }^{71}$ Ramos, M. E., Robles, A. B. \& González-Rebollar, J. L. Ley-farming and seed dispersal by 517 sheep: Two methods for improving fallow pastures in semiarid Mediterranean environments? 518 Agric. Ecosyst. Environ. 137, 124-132 (2010). 
51972 Boatman, N. D., Brickle, N. W., Hart, J. D., Milsom, T. P., Morris, A. J., Murray, A. W., 520 Murray, K.A. \& Robertson, P. A. Evidence for the indirect effects of pesticides on farmland 521 birds. Ibis 146, 131-143 (2004).

52273 Chiron, F., Chargé, R., Julliard, R., Jiguet, F. \& Muratet, A. Pesticide doses, landscape 523 structure and their relative effects on farmland birds. Agric. Ecosyst. Environ. 185, 153-160 524 (2014).

52574 Santangeli, A., Di Minin, E. \& Arroyo, B. Bridging the research implementation gap. 526 Identifying cost-effective protection measures for Montagu's harrier nests in Spanish farmlands. 527 Biol. Conserv. 177, 126-133. (2014).

52875 De Frutos, A., Olea, P. P. \& Mateo-Tomás, P. Responses of medium-and large-sized bird 529 diversity to irrigation in dry cereal agroecosystems across spatial scales. Agric. Ecosyst. Environ. 530 207, 141-152. (2015).

53176 Casas, F. et al. Are trellis vineyards avoided? Examining how vineyard types affect the 532 distribution of great bustards. Agric. Ecosyst. Environ. 289, 106734 (2020)

53377 Santangeli, A., Lehikoinen, A., Lindholm, T. \& Herzon, I. Organic animal farms increase 534 farmland bird abundance in the boreal region. PloS One, 14, e0216009. (2019).

$535{ }^{78}$ Evans, D. M. et al. Low intensity, mixed livestock grazing improves the breeding abundance 536 of a common insectivorous passerine. Biol. Lett. 2, 636-638 (2006).

$537{ }^{79}$ Murray, C., Minderman, J., Allison, J. \& Calladine, J. Vegetation structure influences foraging 538 decisions in a declining grassland bird: the importance of fine-scale habitat and grazing regime. 539 Bird Study 63, 223-232 (2016).

$540{ }^{80}$ Malo, J.E. \& Suárez, F. Herbivorous mammals as seed dispersers in a Mediterranean dehesa. 541 Oecologia 104, 246-255 (1995). 
$542{ }^{81}$ González-Rebollar, J.L. \& Ruiz-Mirazo, J El papel del ganado doméstico en la naturalización

543 del monte mediterráneo. Pastos 43, 7-12 (2013).

$544{ }^{82}$ Le Hourèou, H.N. Impact of man and his animals on Mediterranean vegetation. In: Di Castri,

545 F., Goodall, D.W., Spetch, R.L. (Eds.), Ecosystems of the world, Vol. 11. Elsevier, New York, 546 NY, 643 pp (1991).

$547{ }^{83}$ Dormont, L., Rapior, S., McKey, D. B. \& Lumaret, J. P. Influence of dung volatiles on the 548 process of resource selection by coprophagous beetles. Chemoecology 17, 23-30 (2007).

54984 Prather, R.M. \& Kaspari, M. Plants regulate grassland arthropod communities through 550 biomass, quality, and habitat heterogeneity. Ecosphere 10, e02909 (2019).

$551{ }^{85}$ Naylor, R., Steinfeld, H., Falcon, W., Galloway, J., Smil, V., Bradford, E., Alder, J. \&

552 Mooney, H. 2005. Losing the links between livestock and land. Sci. 310, 1621-1622 (2005).

$553{ }^{86}$ O'Brien, D., Bohan, A., McHugh, N. \& Shalloo, L. A life cycle assessment of the effect of 554 intensification on the environmental impacts and resource use of grass-based sheep farming. 555 Agric. Syst. 148, 95-104 (2016).

$556{ }^{87}$ Pulido, M., Schnabel, S., Lavado Contador, J. F., Lozano-Parra, J. \& González, F. The impact 557 of heavy grazing on soil quality and pasture production in rangelands of SW Spain. Land Degr. 558 Develop. 29, 219-230 (2018).

$559{ }^{88}$ Gibbons, D.W., Wilson, J.D. \& Green, R.E. Using conservation science to solve conservation 560 problems. J. App. Ecol. 48, 505-508 (2011).

$561{ }^{89}$ Menz, M. H., Brotons, L. \& Arlettaz, R. Habitat selection by Ortolan Buntings Emberiza 562 hortulana in post-fire succession in Catalonia: implications for the conservation of farmland 563 populations. Ibis 151, 752-761 (2009). 
$564{ }^{90}$ Pérez-Granados, C., Serrano-Davies, E. \& Noguerales, V. Returning home after fire: how fire 565 may help us manage the persistence of scrub-steppe specialist bird populations. Biod. Conserv. 566 27, 3087-3102(2018).

56791 Hellicar, M. A. \& Kirschel, A. N. Grazing pressure and the interaction dynamics of the 568 endemic Cyprus Warbler Sylvia melanothorax and its recently colonising congener the Sardinian 569 Warbler S. melanocephala. Bird Conserv. Int. 31(2): 239-254. (2020).

570 
Figure 1

Temporal trend in the number of sheep in Spain during the period 1992-2020.

The linear regression is shown in blue, and 95\% Confidence Intervals in grey (linear regression: adjusted $\mathrm{R}^{2}=0.82 ; \mathrm{p}<0.0001$ ).

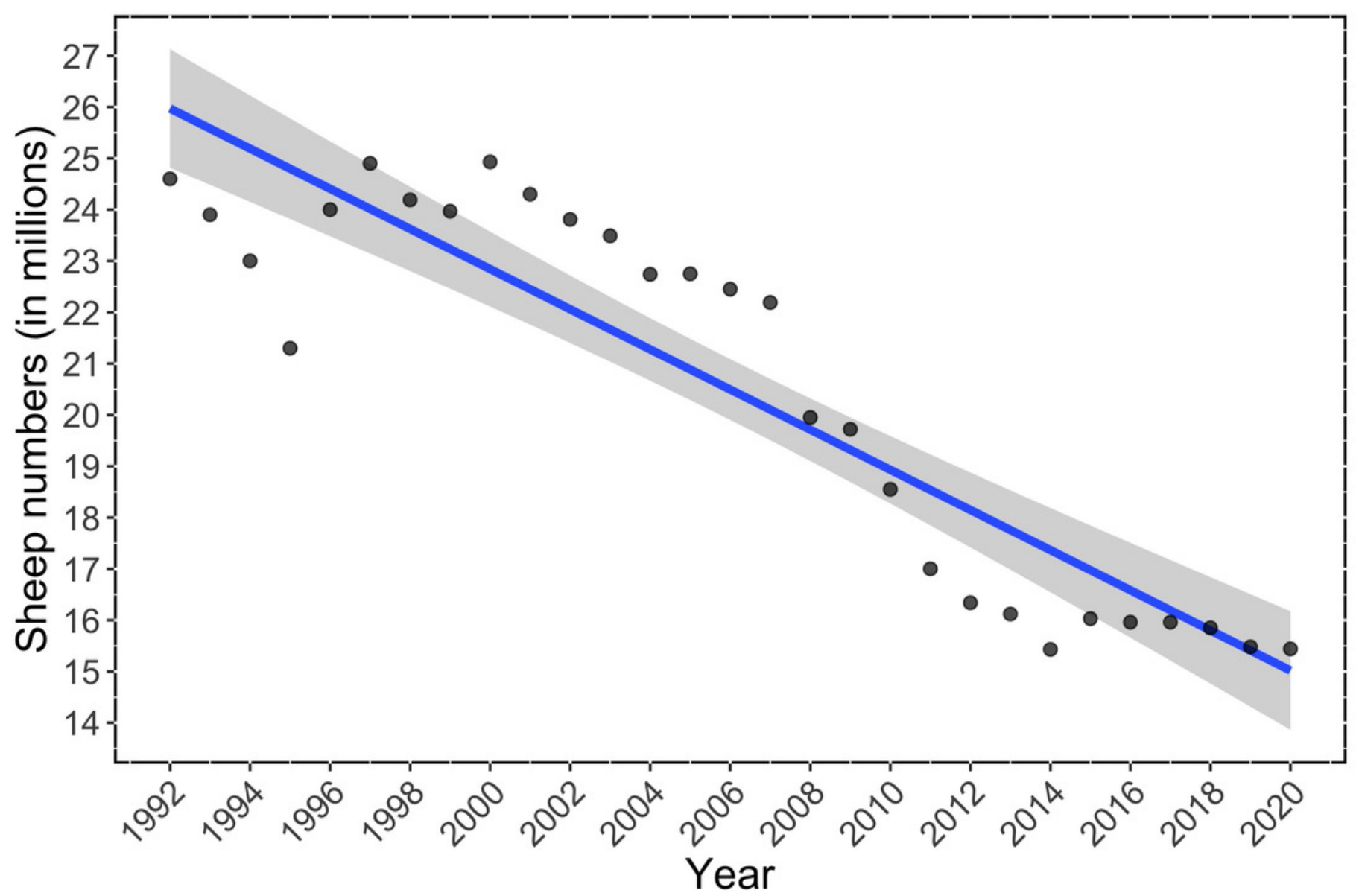


Figure 2

Linear relationship between trends of bird communities and trend of sheep abundance in Spain during the period 1998-2018. All variables are represented as the percent reduction using the year 1998 as the reference value (0).

(A) Farmland Bird Index (adjusted $R^{2}=0.66 ; p<0.0001$ ). (B) Steppe Bird Index (adjusted $R^{2}$ $=0.56 ; p<0.001)$. 

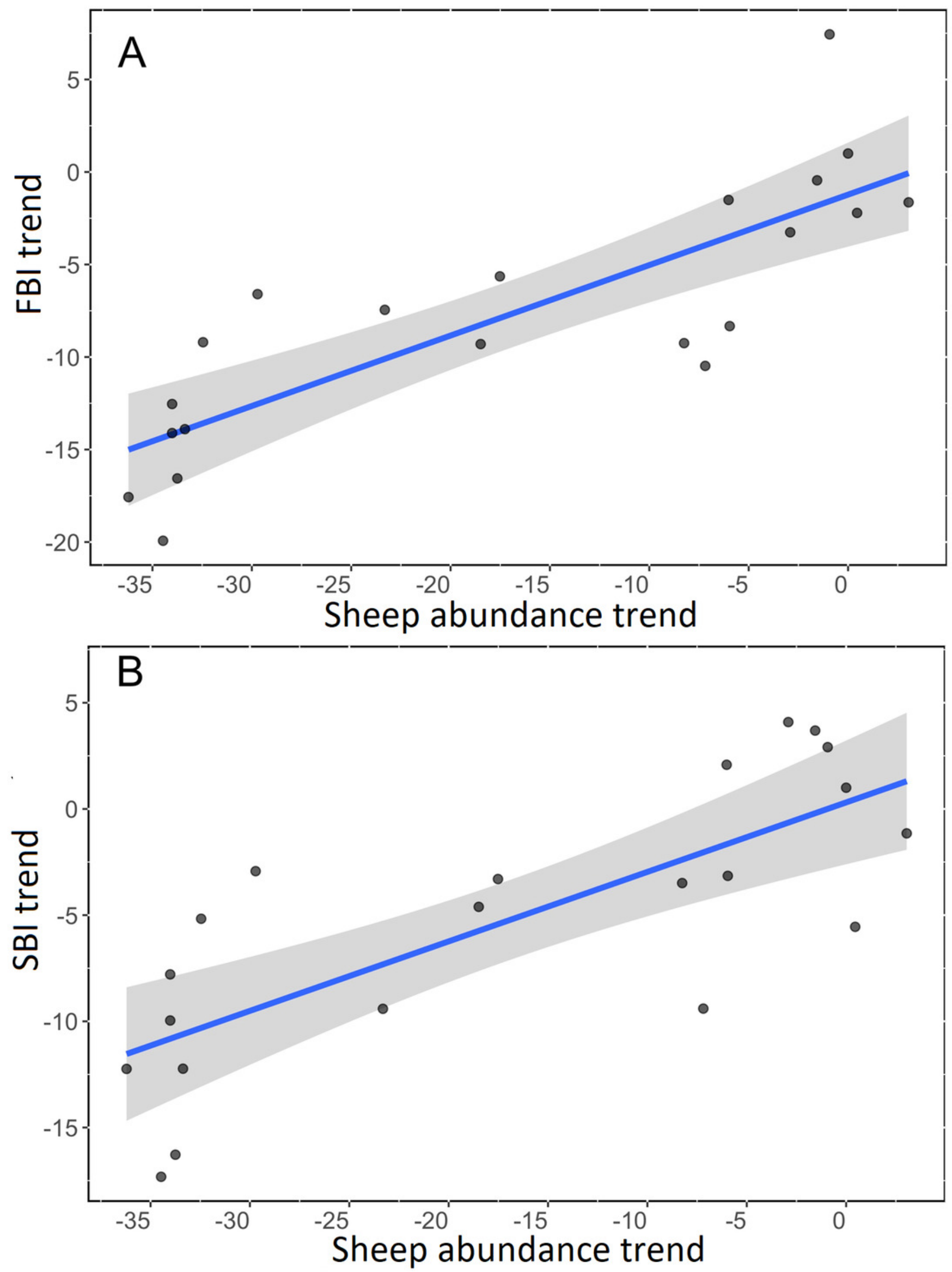

PeerJ reviewing PDF | (2021:10:66525:4:0:NEW 10 Jan 2022) 
Figure 3

Linear relationship between Dupont's Lark trend and trend of sheep abundance in Spain during the period 2004-2015 (adjusted $R^{2}=0.25 ; p<0.0649$ ). Both variables are represented as the percent reduction using the year 2004 as the reference valu

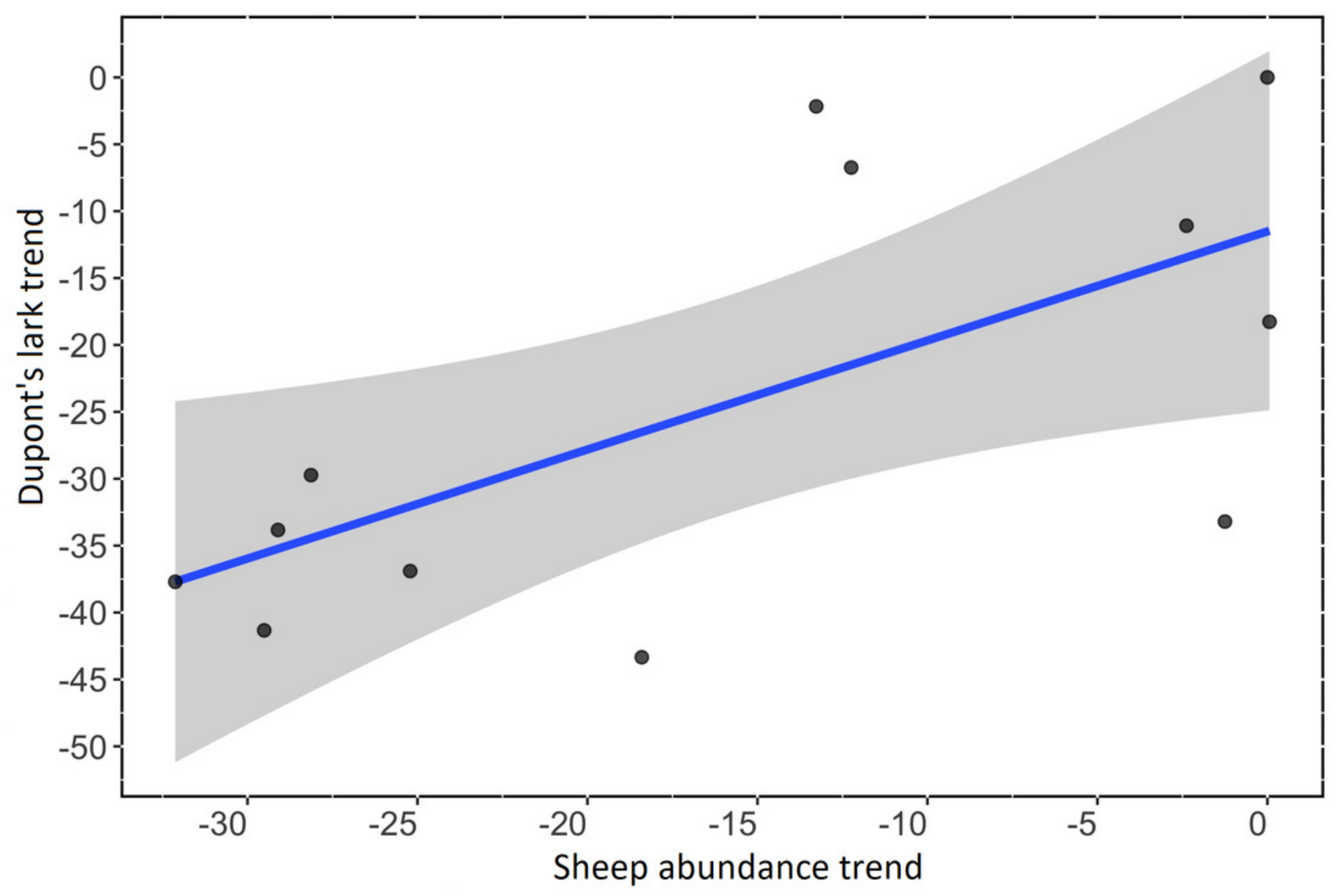

